\title{
Risk assessment and mapping of extreme floods in non-dyked communities along the Elbe and Mulde Rivers
}

\author{
K.-E. Lindenschmidt ${ }^{1}$, U. Herrmann ${ }^{1}$, I. Pech ${ }^{1}$, U. Suhr ${ }^{2}$, H. Apel ${ }^{1}$, and A. Thieken ${ }^{1}$ \\ ${ }^{1}$ GFZ GeoForschungsZentrum Potsdam, Section 5.4 - Engineering Hydrology, Telegrafenberg, 14473 Potsdam, Germany \\ ${ }^{2}$ UFZ - Centre for Environmental Research, Dept. Hydrological Modelling, Brückstr. 3a, 39114 Magdeburg, Germany
}

Received: 23 January 2006 - Revised: 22 May 2006 - Accepted: 3 July 2006 - Published: 26 September 2006

\begin{abstract}
Assessing and mapping damage risk of floods for large river basins is still in its infancy. Damage risk is understood to be the combination of flood hazard and the vulnerability of communities to a flood of a particular return period. Risk is calculated and mapped for two communities in which dykes are not located for flood protection: Meissen on the Elbe River and Döbeln in the Mulde catchment. Different methodologies for the computation of flood depth and inundation extent of varying flood return periods (hazard) are compared. Exposure and relative damage to the flooding (vulnerability) based on land-use coverages of different scale are also compared and discussed. A property asset coverage completes the data requirements for the construction of the risk maps. Recommendations for continued research on risk assessments of large river basins conclude the study.
\end{abstract}

\section{Introduction}

An important prerequisite for developing provision management concepts for the mitigation of damages from extreme flood events is to identify areas of potentially high risk to such events (Lindenschmidt et al., 2005). In this context, risk is defined as the probability that a given loss will occur. Thus, risk encompasses both, hazard and vulnerability. For a quantitative risk analysis several events that cover a broad range of event probabilities should be investigated. Typical outcomes of a risk assessment are the expected annual damage or a more detailed risk curve that shows the exceedance probabilities and corresponding losses for different events (e.g. Merz and Thieken, 2004). Risk maps are extremely useful, however methodologies for very large river basins are still rare. Kron and Willems (2002) identify eight independent regional loss accumulation zones in Germany in which prob-

Correspondence to: K.-E. Lindenschmidt (kel@gfz-potsdam.de) able maximum losses are calculated for five different flood scenarios corresponding to return periods ranging from 10 to 200 years. Zoning is carried out, not of rivers alone, but of entire large catchment areas. The system has been used by a reinsurance company. Similar efforts for Germany have been carried out by Kleeberg (2001), who concentrated the zoning to the flood regions along rivers and who implemented the method in the software package ZÜRS (Zoning System for Floods, Backwater and Heavy Rains) that has been used by insurance companies. In the UK, Rodda and Berger (2002) established differentiated risk zones in the flooded areas near the river itself, and Hall et al. (2003) and Sayers et al. (2002) have extended this approach to include the probabilities of dyke failures. The implementation of dyke fragility curves has also found application in the USA (USACE, 1996, 1999). These methods provide a rough orientation of where "hot spots" occur in terms of flood risk on very large (nationwide) scales. These have their justification for high-level strategic planning for entire countries and provide information on a scale that is valuable for re-insurance companies, which base their policies on probable maximum loss estimates. The downside of these methods is that the spatial resolution is generally too coarse and the results not differentiated enough to be applicable for the development of mitigation concepts.

Additional efforts in quantifying risk at higher resolutions have been documented in an atlas for the River Rhine between Lake Constance and Rotterdam (ICPR, 2001). Flood hazard is defined in categories of flood depth $\left(0-\frac{1}{2} \mathrm{~m}, \frac{1}{2}-2 \mathrm{~m}\right.$, $2-4 \mathrm{~m},>4 \mathrm{~m}$ ) and the number of persons at risk. Vulnerability is defined in five categories of possible damages due to extreme floods or dyke failures (in settlements less or greater than $50 \mathrm{EUR} / \mathrm{m}^{2}$; in regions of industry, trade, infrastructure and transport less or greater than $25 \mathrm{EUR} / \mathrm{m}^{2}$; agricultural land surfaces less than $1 \mathrm{EUR} / \mathrm{m}^{2}$ ) and is based on the CORINE land-use classification. The aim of the atlas was to draw the attention of citizens at risk along the Rhine and to provide a basis for the Rhine Action Plan with the mandate

Published by Copernicus GmbH on behalf of the European Geosciences Union. 


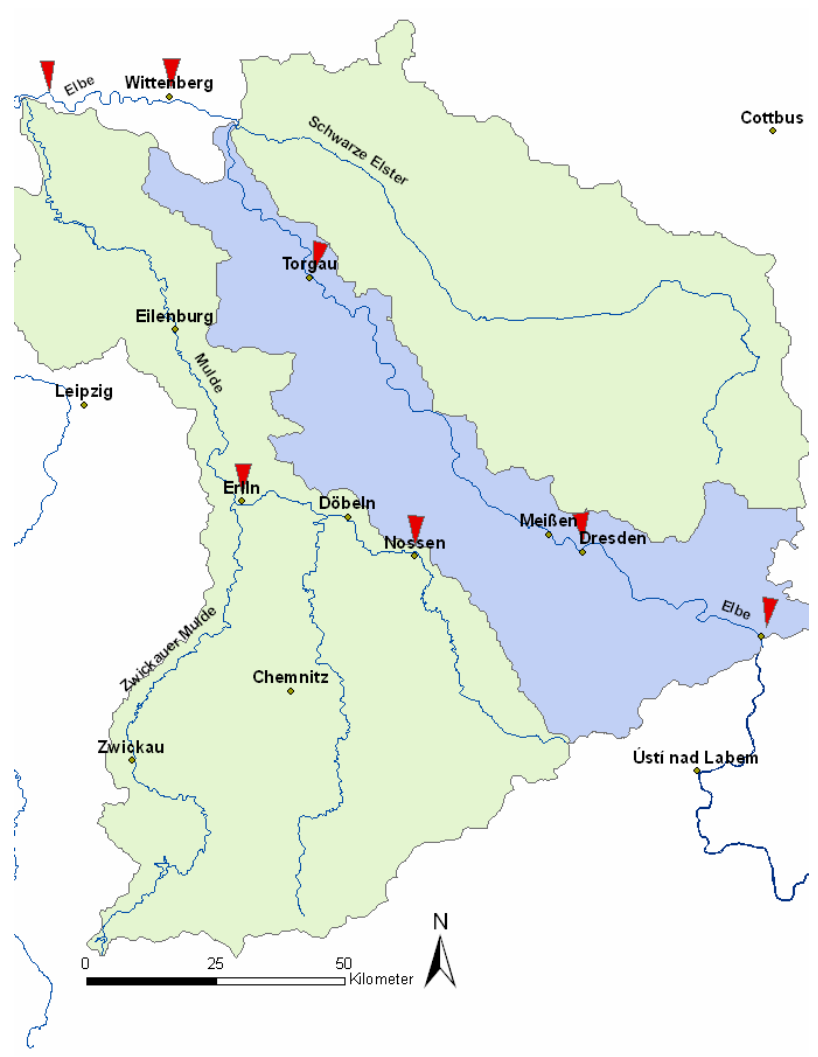

Fig. 1. Risk map are presented for the communities of Meissen on the Elbe River and Döbeln in the Mulde catchment. Red triangles represent stream gauges.

of providing better protection of humans and material assets against flooding and improve the ecological state of the river and its floodplains. Only the extent of floods with return periods of 10 and 100 years and an extreme flood were considered. Risk calculations were not carried out.

Similar efforts were carried out for large rivers in Saxony and documented in an atlas (LfUG, 2005). Flood intensity is defined both as flood depth (same categories as Rhine atlas) and specific discharge (flow velocity $\times$ flood depth: $0-\frac{1}{2} \mathrm{~m}^{2} / \mathrm{s}, \frac{1}{2}-2 \mathrm{~m}^{2} / \mathrm{s},>2 \mathrm{~m}^{2} / \mathrm{s}$ ), which is similar to the flood hazard specification developed in Switzerland (BWW, 1997; BWG, 2001). Vulnerability calculations are based on ATKIS land-use data and categorised into industrial (two classes: one less and the other greater than $\left.10 \mathrm{EUR} / \mathrm{m}^{2}\right)$, settlement $\left(<10 \mathrm{EUR} / \mathrm{m}^{2}, 10-50 \mathrm{EUR} / \mathrm{m}^{2},>50 \mathrm{EUR} / \mathrm{m}^{2}\right)$ and agricultural and forestry regions $\left(1 \mathrm{EUR} / \mathrm{m}^{2}\right)$. Risk calculations were not carried out however, points of high risk such as electrical generators and transformers, water supply facilities, industries with high damage potential, hospitals and wastewater treatment plants are indicated.

In this study a similar methodology is pursued as that used for the Rhine atlas, with the addition of risk assessment for the city of Meissen on the Elbe River and the city of Döbeln in the Mulde catchment. The river sections at these communities are of different Strahler stream order and were chosen to assess scale differences on risk assessment. The scale difference is due to the difference in stream order of the communities investigated. The hazard $\times$ vulnerability approach is used for risk calculations and mapping for several flood events of varying return periods. Different methods are described and compared for the computation of flood depths and inundation extent for the construction of hazard maps. Vulnerability mapping based on land-use coverages of different resolution is compared. The implications of using landuse data of different scale on the subsequent risk calculations and mapping are discussed. Conclusions of the risk assessment and an outlook for future research close the paper.

\section{Study areas}

Risk maps are presented from two cities: Meissen on the Elbe River (Elbe-km $\approx 82$ ) and Döbeln on the Freiberger Mulde (F.Mulde-km $\approx 24$ ), a tributary of the Mulde River (see Fig. 1). Both areas are situated in incised valleys and dykes for flood protection are not present in their vicinities. The Strahler order of the Elbe at Meissen and of the Freiberger Mulde at Döbeln are 6 and 4, respectively. Discharge characteristics of the first gage upstream and the first gage downstream from the study sites are given in Table 1. All areas were heavily affected by the August 2002 flood.

\section{Damage risk assessment}

Risk is defined as the probability of the adverse effects of a natural process such as a flood exceeding a certain magnitude (intensity) from which certain damages and losses occur (vulnerability) (Merz et al., 2006).

In damage risk assessment, hazard must first be determined, which incorporates a frequency analysis of the intensity of the threatening occurrence (see Fig. 2). In our case, the occurrence is a flood event and the intensity of the event is measured by the depth and extent of the flooding. Damage occurs through flooding and increases with the intensity of the event. This is the basis for vulnerability. The vulnerability curve reaches an asymptote at high degrees of intensity since a point of maximum damage corresponding to the total assets in the flooded area can theoretically be attained. (An asymptote can theoretically be attained for hazard, especially in large river basins, in which the flood magnitude approaches an upper limit called the probable maximum flood. However, this limit is not as easily defined as for vulnerability). Transferring damage costs to a probability of the damages being attained or exceeded forms the risk curve. The area under this curve is the damage expectation for the studied area.

To aid risk assessment risk can also be mapped for areas of flooding. The probability of exceedance (expressed 
Table 1. Discharge characteristics of the gages immediately upstream and downstream from the study sites (see also Fig. 1).

\begin{tabular}{|c|c|c|c|c|c|c|c|}
\hline Gage & Elbe-km ${ }^{1}$ & F.Mulde-km² & $M Q^{3}$ & $\mathrm{MHQ}^{4}$ & $\mathrm{HHQ}^{5}$ & Date of $\mathrm{HQ}$ & Series \\
\hline \multicolumn{8}{|l|}{ Elbe } \\
\hline Dresden & 55,6 & - & 327 & 1460 & 4580 & 16-Aug-2002 & 1931 to 2003 \\
\hline Torgau & 154,2 & - & 344 & 1420 & 4420 & 17-Aug-2002 & 1936 to 2003 \\
\hline \multicolumn{8}{|c|}{ Freiberger Mulde } \\
\hline Nossen & - & 47,2 & 6,81 & 68,7 & 690 & 12-Aug-2002 & 1926 to 2003 \\
\hline Erlln & - & 1,5 & 35 & 300 & $610^{6}$ & $08-D e c-1970^{6}$ & 1961 to 2003 \\
\hline
\end{tabular}

also as a return period $=1$ /exceedance probability) together with the intensity of the event (usually expressed in terms of flood depth or inundation) establishes the hazard induced by the flood event (see Fig. 3). Using land-use information and damage costs as functions of water depth and perhaps other factors (i.e. flow velocities) the vulnerability of certain landuse types that are exposed to the flood and their susceptibility to damage by the flooding can be assessed. Both hazard and vulnerability are combined to calculate risk and can be used to establish risk maps. Once areas of exceptionally high risk ("hot spots") have been identified scenarios can be run to test various management concepts for flood mitigation.

\section{Risk mapping at Meissen (Elbe River)}

Different methodologies were used to construct risk maps for the communities on the Elbe and Mulde Rivers, depending on the data and tools available. The steps taken to construct the risk maps at Meissen on the Elbe River are as follows (see also Fig. 4):

1. A flood frequency analysis of the maximum annual flood peaks was carried out for all the discharge gages along the upper German Elbe River. These include the gages at Schmilka, Dresden, Meissen, Torgau and Wittenberg. The return periods were estimated on the basis of annual maximum discharge series and the generalised extreme value (GEV) distribution estimated using L-moments.

2. Using the hydraulic model QSIM the water levels along the Elbe between Schmilka and Wittenberg were simulated every $500 \mathrm{~m}$ along the river stretch. QSIM (Quality Simulation) is a water quality model developed by the Federal Institute of Hydrology, Germany (Kirchesch and Schöl, 1999) with a focus on navigable rivers to analyse the environmental impacts of river control measures and constructions on the rivers' aquatic ecosystems. The hydraulic module uses the KalininMiljukov technique to route flow hydrographs and to

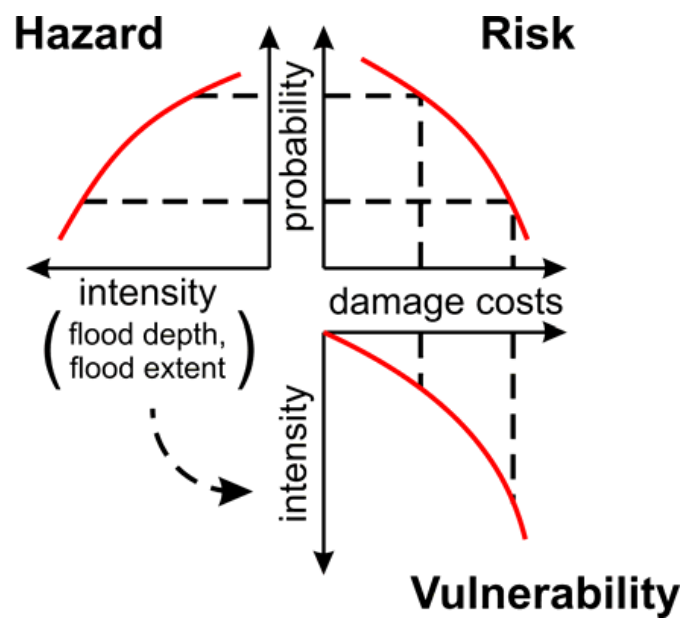

Fig. 2. Graphical representations of hazard and vulnerability in the computation of damage flood risk.

subsequently calculate water levels, details of which are given in Plate et al. (1977) and Patt et al. (2001).

3. Using the Watershed Modelling System (WMS) (http: //www.ems-i.com) the flood depths and extent were calculated based on digital elevation maps with a point resolution every $5 \mathrm{~m}$ for the river corridor and every $25 \mathrm{~m}$ for the hinterland. WMS is a comprehensive graphical modelling environment for all phases of watershed hydrology and hydraulics and includes tools to automate modelling processes such as basin delineation, geometric parameter calculations, GIS overlay computations and floodplain delineation and mapping.

4. Exposition is calculated by overlaying the hazard map with either the ATKIS or CORINE digital land-use map. All mapping was carried out using ArcGIS (http: //www.esri.com/). ATKIS (Amtliches Topographisches Informationssystem) (http://www.atkis.de/) is a service by the German survey administration providing digital 


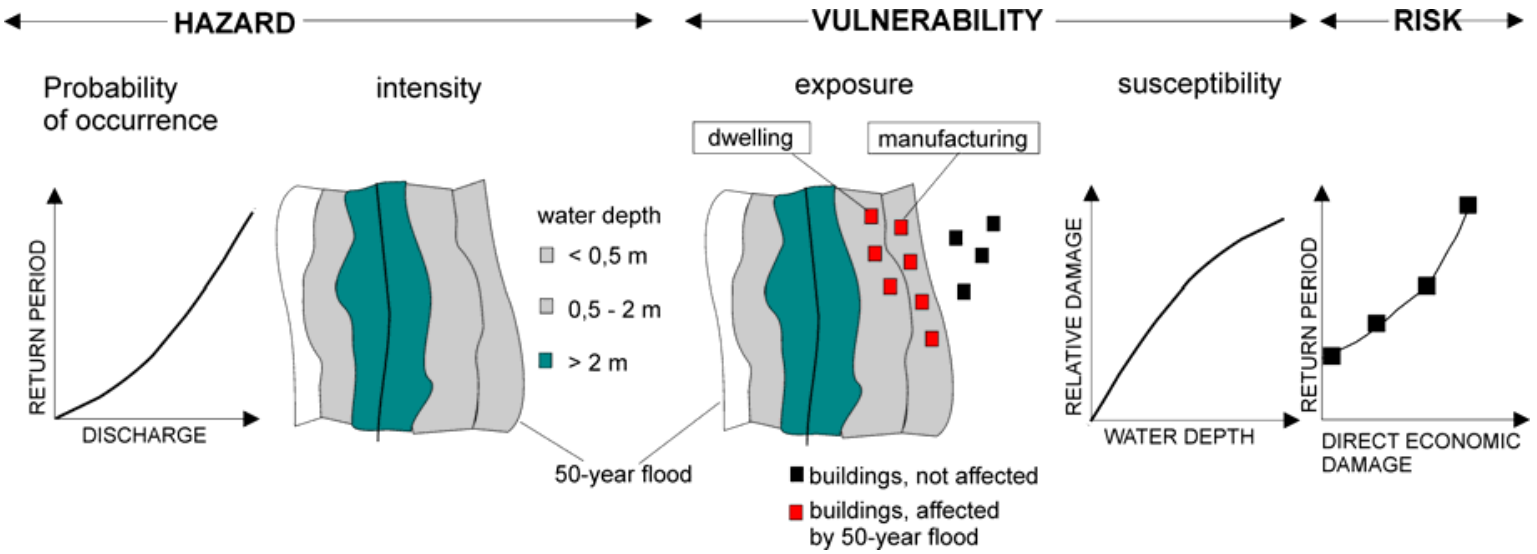

Fig. 3. Flood risk as interaction of hazard and vulnerability (adapted from Merz and Thieken, 2004).

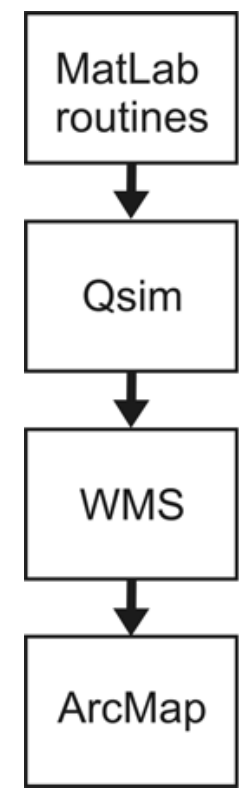

Flood frequency analysis

Simulations of water levels

\section{Deliniation of flood extent}

\section{Mapping hazard, vulnerability \& risk}

Fig. 4. Methodology in mapping hazard, vulnerability and risk for the city of Meissen on the Elbe River.

land-use, elevation and topography maps. The landuse map with the finest resolution (1:25000) was used. The CORINE Land Cover project (http://www.corine. dfd.dlr.de) provides area-wide land use (from the years 1990 and 2000) and land-use change maps based on remote sensing data. Its scale is 1:100 000 .

5. Relative damage functions for the land-use types of interest were used to map vulnerability. Examples of damage functions in which the percentage of damage degree $y$ is a function of flood depth $x$ are:

ATKIS land cover (MURL, 2000; http://www.proaqua-gmbh.de/hws/hwsnrw/hws/)

$y=27 \sqrt{x}$ (industry\&services)

$y=\frac{a \cdot x+b \sqrt{x}}{1.95583}($ residential $)$

where $a$ and $b$ are coefficients depending if a basement is present or not.

CORINE land cover (http://www.rheinatlas.de/H)

$y=2 x^{2}+2 x($ residential, real estate $)$

$y=11.4 x+12.625$ (residential, household contents)

6. The vulnerability map from the previous step and a property asset value map (Kleist et al., 2004; Thieken et al., 2006) are overlain to map risk for the flood of a particular return period. The asset map contains estimates of the asset values of residential buildings for each community in Germany on the basis of census data on the number of buildings per community provided by INFAS Geodaten $\mathrm{GmbH}$, census data on the floor area in residential buildings per district provided by the Federal Statistical Office in Germany and standardised reconstruction costs per square meter published by the Ministry of Transport, Construction and Housing. The algorithm is outlined in Kleist et al. (2004). Thieken et al. (2006) show how the asset estimates per community can be disaggregated to CORINE land-use classes by the use of a disaggregation scheme (dasymetric mapping). Assets from industrial areas are not mapped and were assumed to be $20 \%$ less than those of residential assets. This proportion was applied by LfUG (2005) for the construction of their vulnerability maps. 


\section{Risk mapping at Döbeln (Mulde River)}

Steps in constructing risk maps for Döbeln on the Freiberger Mulde River are (see also Fig. 5):

1. A flood frequency analysis was carried out using selfprogrammed MatLab routines as described in Apel et al. (2004). There is no discharge gage at Döbeln, hence data from the next upstream gage at Nossen was taken for the analysis. The series of annual maximum discharges for 76 continuous years from 1925 to 2003 was available to which the general extreme value probability distribution estimated using L-moments gave the best fit. The fit provided the discharges for flood return periods of 10, 20, 50, 100, 200, 500 and 1000 years, which were used as input for the subsequent hydraulic simulations.

2. The LISFLOOD-FP program (Bates and De Roo, 2000) was used to simulate flood depths and inundation extents. The program is a raster flood inundation model for simulating flood spreading, with output consisting of raster maps of water depth in each grid square at each time step and predicted stage and discharge hydrographs at the outlet of the reach. The kinematic approximation to the one-dimensional St. Venant equations is used to simulate the passage of a flood wave along a channel reach. Two dimensional flood spreading using the diffusion wave analogy of the St. Venant equations and storage cells applied over a raster grid simulates water movement from the channel to adjacent floodplains. The spatial resolution in our inundation simulations is $25 \mathrm{~m}$. The synthetic flood waves were derived via characteristic normalized flood waves of the river extracted by a cluster analysis of the recorded annual maximum flood waves (see Apel et al., 2004). The mean daily flood peak discharges for the single return periods drawn from the GEV were further scaled to subdaily flash flood discharges based on a regression relation between mean daily flood peak discharges and the actual recorded peak discharges of the event.

3. The mapping of hazard and vulnerability and the subsequent calculations and mapping of risk follow the same procedure already described above in Steps iv) to vi) for Meissen on the Elbe River.

\section{Conclusions}

Results and discussion

\subsection{Risk mapping of Meissen (Elbe) for $\mathrm{HQ}_{100}$}

The flood extent for the flood of return period 100 years in the city of Meissen is given in Fig. 6a. At some points, the

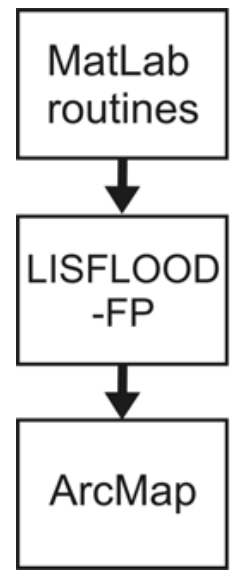

\section{Flood frequency analysis}

\section{Simulations of flood depth \& extent}

\section{Mapping hazard, vulnerability \& risk}

Fig. 5. Methodology in mapping hazard, vulnerability and risk for the city of Döbeln on the Freiberger Mulde River.

width of the flood extends over $1000 \mathrm{~m}$ across the river. This map is used as the hazard layer for risk constructs based on both ATKIS and CORINE land covers. Four classifications are present in the area with ATKIS data (Fig. 6b) of which mostly residences are flooded by the event. The maximum damage attained by this 100 year flood is $78 \mathrm{EUR} / \mathrm{m}^{2}$ for mixed usage which includes settlements) (Fig. 6c). The study area is partitioned by only three CORINE land-use classifications, as shown in Fig. 6d. Settlements are by far the most flooded by this event. Damage costs (see Fig. 6e) reach nearly $160 \mathrm{EUR} / \mathrm{m}^{2}$, which is twice that attained by the ATKIS data. The high costs occur along the banks of the river and are due to the coarse grained resolution of CORINE data. There is an overlap at some locations between land use near the river bank and the river geomorphology itself causing an overestimation of flood depths. It is recommended that these areas of overestimated damage are filtered using a precise overlay coverage of the river bank. The extent of damage also covers a larger area than for the more land-use differentiated ATKIS data. Due to the low-grain resolution of the CORINE land cover, flood damage is allocated in areas where little damage is expected to occur.

A large uncertainty exists in the values used for the property assets. The asset values used here from Thieken et al. (2006) are only $40 \%$ of those values from LfUG (2005). Hence, there is a large discrepancy in the risk calculations by the same proportion.

\subsection{Risk mapping of Döbeln (Mulde) for $\mathrm{HQ}_{100}$}

The extent and depths of the flood with a return period of 100 years are shown for Döbeln in Fig. 7a. The river appears branched, however, the upper diversion is the actual river with the lower branch being a shallow ditch which fills with water during floods. In the branched section, the width of the 
(a) Hazard map

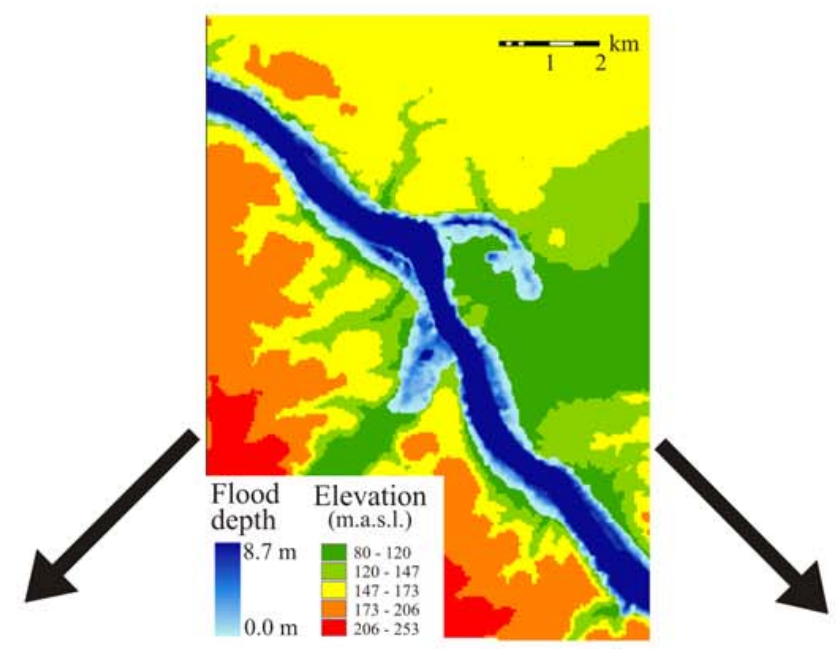

(b) Vulnerability map (ATKIS)

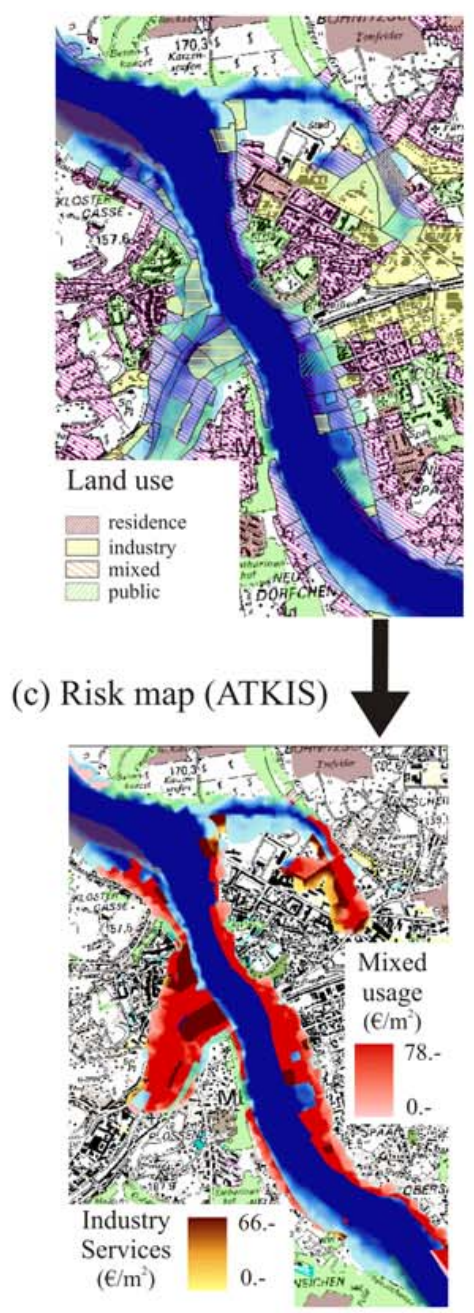

(d) Vulnerability map (CORINE)
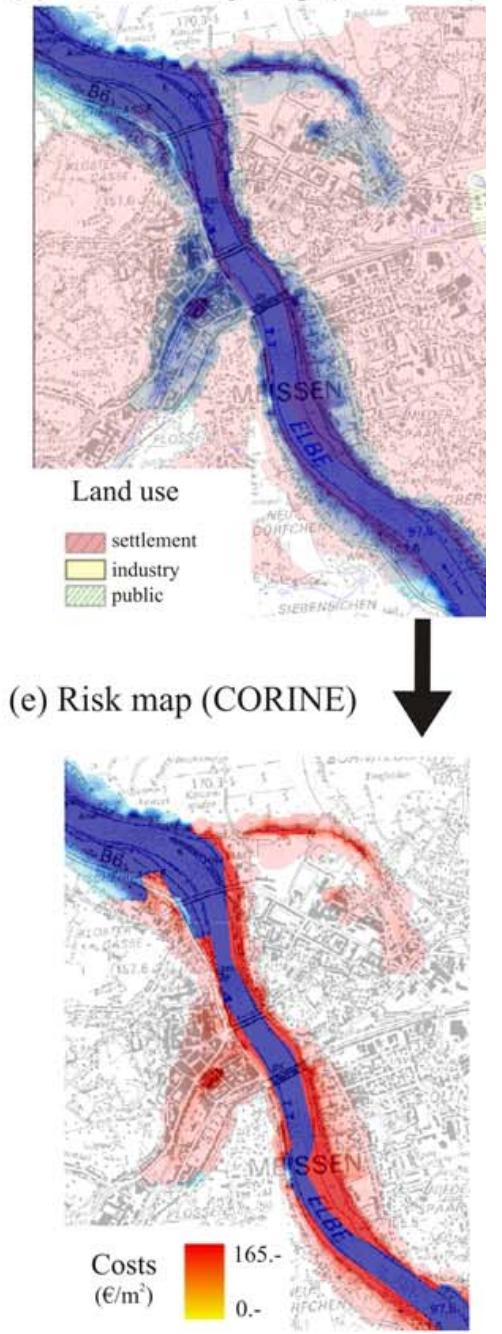

Fig. 6. Hazards, vulnerability and damage risk maps for a flood with a return period of 100 years in the city of Meissen on the Elbe River. 
(a) Hazard map

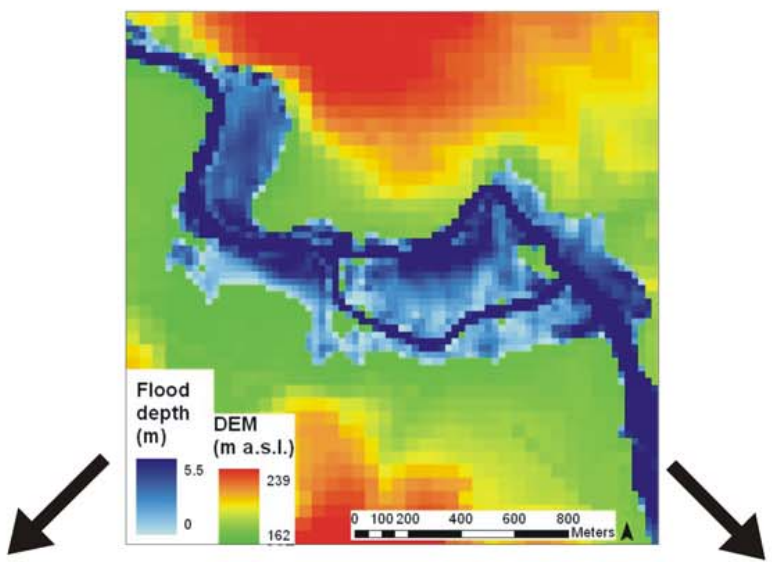

(b) Vulnerability map (ATKIS)

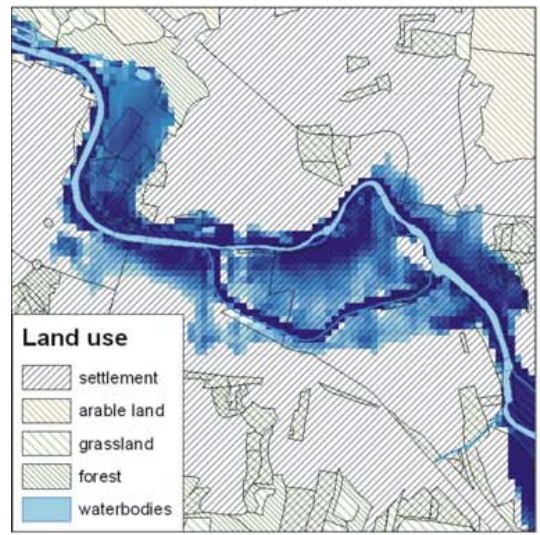

(c) Risk map (ATKIS)

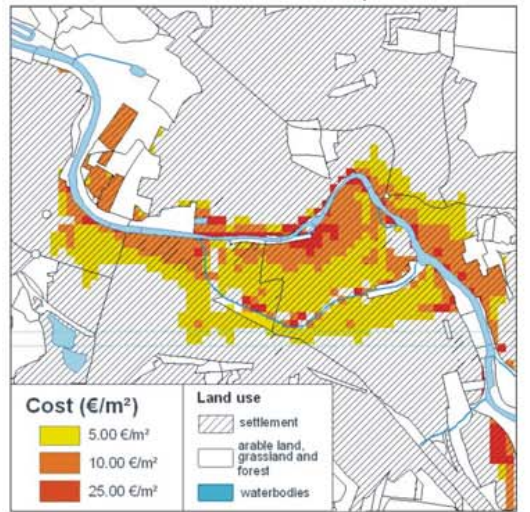

(d) Vulnerability map (CORINE)
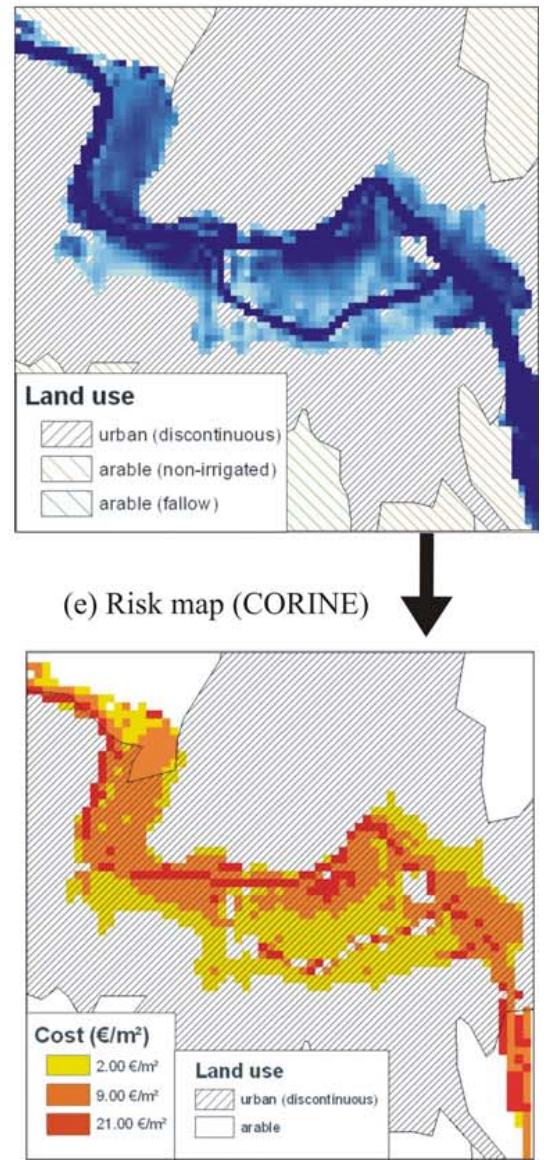

Fig. 7. Hazards, vulnerability and damage risk maps for the flood with a return period of 100 years in the city of Döbeln in the Mulde catchment.

flooding extends $600 \mathrm{~m}$ across the river. The water course appears only in the ATKIS land-use coverage (see Fig. 7b), not in the CORINE database (see Fig. 7d), due to the small scale of the river in this area. The former land-use map contains some forested areas that are flooded on the right river bank in the top left corner of Fig. 7b. These areas are classified with very little relative flood susceptibility and no risk is assigned to them in the risk maps in Fig. 7c. The forested area is too small for it to be registered as such in the CORINE land-use map in Fig. 7d. The area affected by the flooding is 
almost all urban, even those designated as forested in ATKIS. Hence, the extent of damages in Fig. 7e is far greater than it should be. Damage costs are not as high as those for Meissen and are comparable for the two land-use databases. As was the case for Meissen, damages along the river bank are overestimated using the CORINE coverage due to the missing water course. Filtering out these high risk values is again advised using a precise overlay map of the river.

\section{Conclusions}

- As may have been expected, the more fine-grained resolution of the ATKIS land cover provides more accurate flood risk assessments than do the CORINE land cover data. Damage costs and the extent of flood damages are expected to be overestimated when using CORINE data. When using CORINE data, it is recommended that the extreme risk values along the river banks are filtered out using an overlay of an accurate designation of the river course.

- Two methods for constructing hazard maps were exhibited: i) using a hydraulic model to simulate the water levels and delineating the water levels on a digital elevation map to obtain flood depths and extent, and ii) using a hydraulic model which incorporates the floodplain in its simulations. It is recommended to use the latter method since work steps are reduced for the flood delineation for the hydraulic/floodplain model which directly provides the flood depths and extent as simulation output.

- Although the risk assessment of the two studied areas are from rivers of different Strahler order (6 for Meissen and 4 for Döbeln) scale effects can not be observed. This may be due to the limited number of areas investigated.

\section{Outlook for future research}

For future work, we wish to compare risk outcomes between water levels interpolated between actual gage measurements and those computed from model simulations. This comparison may give an orientation on the magnitude of the uncertainty within hazard calculations and its propagation in risk calculations. If the data is available, a comparison with actual flow and inundation depths and extent would surely provide useful information on the uncertainties. The question as to how much hazard and vulnerability contribute to the overall uncertainty in risk assessments for varying extreme discharges still remains unanswered. The analysis should also be carried out on river reaches with dykes. Risk assessments of additional communities along the rivers will also be carried out in order to determine if patterns due to scaling effects arise. A comparison with an analysis of the August 2002 flood is also to be carried out.

Edited by: R. Barthel, J. Götzinger, G. Hartmann, J. Jagelke, V. Rojanschi, and J. Wolf

Reviewed by: anonymous referees

\section{References}

Apel, H., Thieken, A. H., Merz, B., and Blöschl, G.: Flood risk assessment and associated uncertainty, Nat. Hazards Earth Syst. Sci., 4, 295-308, 2004, http://www.nat-hazards-earth-syst-sci.net/4/295/2004/.

Bates, P. D. and De Roo, A. P. J.: A simple raster-based model for floodplain inundation., J. Hydrol., 236, 54-77, 2000.

BWG: Hochwasserschutz an Fließgewässern - Wegleitungen des BWG (Flood protection at lotic waters - a guide from the Federal Institute of Water and Geology), Schweizer Bundesanstalt für Wasser und Geologie, http://www.bwg.admin.ch/ service/katalog/download/804801d.pdf, 2001.

BWW: Berücksichtigung der Hochwassergefahren bei raumwirksamen Tätigkeiten (Flood hazard in consideration of spatial activities), Schweizer Bundesanstalt für Wasserwirtschaft, http://www.bwg.admin.ch/service/katalog/download/pdf/ 804201d.pdf, 1997

Hall, J. W., Dawson, R. J., Sayers, P. B., Rosu, C., Chatterton, J. B., and Deakin, R.: A methodology for nation-scale flood risk assessment, Water Mar. Eng., 156(WM3), 235-247, 2003.

ICPR: Rhine-Atlas. International Commission for the Protection of the Rhine., http://www.rheinatlas.de, 2001.

Kirchesch, V. and Schöl, A.: Das Gewässergütemodell QSIM Ein Instrument zur Simulation und Prognose des Stoffhaushalts und der Planktondynamik von Fließgewässern (The water quality model QSIM - an instrument for the simulation and forecast of the substance regime and plankton dynamics in rivers), Bundesanstalt für Gewässerkunde, Koblenz, Germany, 1999.

Kleeberg, H.-B.: Zur Hochwasser-Risikozonierung der deutschen Versicherungwirtschaft (On flood zoning for the German insurance industry), in: Hochwasser - Niedrigwasser - Risiken, Nürnberger Wasserwirtschaftstage des ATV-DVWK Landesverbandes Bayern, 9-10 May 2001, pp. 39-50, 2001.

Kleist, L., Thieken, A., Köhler, P., Müller, M., Seifert, I., and Werner, U.: Estimation of building values as a basis for a comparative risk assessment, in: Disasters and Society - From Hazard Assessment to Risk Reduction, edited by: Malzahn, D. and Plapp, T., Logos-Verlag, Berlin, pp. 115-122, 2004.

Kron, W. and Willems, W.: Flood risk zoning and loss accumulation analysis for Germany, International Conference on Flood Estimation, 6-8 March 2002, Berne, Switzerland, pp. 549-558, 2002.

LfUG: Hochwasser in Sachsen - Gefahrenhinweisekarte (Floods in Saxony - flood impact maps). Sächsisches Landesamt für Umwelt und Geologie, Zur Wetterwarte 11, 01109 Dresden, Abteilung1@lfug.smul.sachsen.de, 2005.

Lindenschmidt, K.-E., Fleischbein, K., Petrow, T., Vorogushyn, S., Theobald, S., and Merz, B.: Model system and scenario development for the provision management of extreme floods in large river basins, Adv. Geosci., 5, 99-104, 2005, http://www.adv-geosci.net/5/99/2005/. 
Merz, B. and Thieken, A. H. Flood risk analysis: concepts and challenges, Österreichische Wasser- und Abfallwirtschaft, 56(3-4), 27-34, 2004.

Merz, B., Thieken, A. H., and Gocht, M.: Flood risk mapping at the local scale: concepts and challenges, in: Flooding in Europe - Challenges and development in flood risk management, Advances in Natural and Technological Hazards Research, Springer, in press, 2006.

MURL: Potentielle Hochwasserschäden am Rhein in NRW (Potential flood damages on the Rhine River in North Rhine Westfahlia), Ministerium für Umwelt, Raumordnung und Landwirtschaft des Landes Nordrhein-Westfalen, 2000.

Patt, H. (Ed.): Hochwasser-Handbuch - Auswirkungen und Schutz, (Flood Handbook - Effects and Protection), Springer Verlag, 2001.

Plate, E. J., Schultz, G. A., Seus, G. J., and Wittenberg, H.: Ablauf von Hochwasserwellen in Gerinnen (Succession of flood waves in channels), Schriftenreihe des Kuratoriums für Wasser und Kulturbauwesen, Heft 27, Parey, Hamburg, 1977.

Rodda, H. and Berger, A.: The application of flood modelling and mapping for managing flood risk in the UK, International Conference on Flood Estimation, 6-8 March 2002, Berne, Switzerland, pp. 645-650, 2002.
Sayers, P., Hall, J., Dawson, R., Rosu, C., Chatterton, J., and Deakin, R.: Risk assessment of flood and coastal defences for strategic planning (RASP) - a high level methodology, DEFRA Conference of Coastal and River Engineering, Keele University, July 2002.

Thieken, A. H., Müller, M., Kleist, L., Seifert, I., Borst, D., and Werner, U.: Regionalisation of asset values for risk analyses, Nat. Hazards Earth Syst. Sci., 6(2), 167-178, 2006.

USACE: Engineering and design - risk-based analysis for flood damage reduction studies. Pub. \# EM1110-2-1619, US Army Corps of Engineers, Washington, D.C., 203141000,http://www.usace.army.mil/inet/usace-docs/eng-manuals/ em1110-2-1619/toc.html, 1996.

USACE: Risk-based analysis in geotechnical engineering for support of planning studies, Pub. \# ETL 1110-2-556, US Army Corps of Engineers, Washington, D.C., 203141000, http://www.usace.army.mil/inet/usace-docs/eng-tech-ltrs/ etl1110-2-556/toc.html, 1999. 